\title{
Investigation of Molybdate Melts as an Alternative Method of Reprocessing Used Nuclear Fuel
}

Amber L. Hames ${ }^{1,2}$, Peter Tkac ${ }^{2}$, Alena Paulenova ${ }^{1}$, James L. Willit ${ }^{2}$, and Mark A. Williamson ${ }^{2}$

1. Oregon State University 1500 SW Jefferson St. Corvallis, OR 97331

2 Argonne National Laboratory 9700 S Cass Ave. Argonne, IL 60439

1. PDF: Powder Diffraction File

(C) 2016. This manuscript version is made available under the Elsevier user license http://www.elsevier.com/open-access/userlicense/1.0/ 


\begin{abstract}
An investigation of molybdate melts containing sodium molybdate $\left(\mathrm{Na}_{2} \mathrm{MoO}_{4}\right)$ and molybdenum trioxide $\left(\mathrm{MoO}_{3}\right)$ to achieve the separation of uranium from fission products by crystallization has been performed. The separation is based on the difference in solubility of the fission product metal oxides compared to the uranium oxide or molybdate in the molybdate melt. The molybdate melt dissolves uranium dioxide at high temperatures, and upon cooling, uranium precipitates as uranium dioxide or molybdate, whereas the fission product metals remain soluble in the melt. Small-scale experiments using gram quantities of uranium dioxide have been performed to investigate the feasibility of $\mathrm{UO}_{2}$ purification from the fission products. The composition of the uranium precipitate as well as data for partitioning of several fission product surrogates between the uranium precipitate and molybdate melt for various melt compositions are presented and discussed. The fission products $\mathrm{Cs}, \mathrm{Sr}, \mathrm{Ru}$ and $\mathrm{Rh}$ all displayed very large distribution ratios. The fission products $\mathrm{Zr}, \mathrm{Pd}$, and the lanthanides also displayed good distribution ratios (D>10). A melt consisting of $20 \mathrm{wt} \% \mathrm{MoO}_{3}-50 \mathrm{wt} \% \mathrm{Na}_{2} \mathrm{MoO}_{4}-30 \mathrm{wt} \% \mathrm{UO}_{2}$ heated to $1313 \mathrm{~K}$ and cooled to $1123 \mathrm{~K}$ for the physical separation of the $\mathrm{UO}_{2}$ product from the melt, and washed once with $\mathrm{Na}_{2} \mathrm{MoO}_{4}$ displays optimum conditions for separation of the $\mathrm{UO}_{2}$ from the fission products.
\end{abstract}

\title{
Keywords
}

Used nuclear fuel recycle; Modified open fuel cycle; Uranium behavior in molybdate melts; Uranium separation; Recrystallization 


\section{Introduction}

Pyrochemical processes are very attractive for recycling short-cooled used nuclear fuel due to the use of inorganic salts since they are more resilient against radiolytic processes than the aqueous or organic solvents, which are used in solvent extraction processes. [1-3] In addition, the use of inorganic salts has the potential to significantly reduce the volume of waste produced during the processing compared to solvent extraction processes.[1-3] Generally, halide-based molten salts have been used as electrolytes in electrorefining used nuclear fuel; [1-3]however, Ustinov et al. have explored molybdate melts for an alternative pyrochemical processing technique, specifically for oxide fuel treatment. [4-9] We explored this alternative approach in developing a so-called modified open fuel cycle in which the actinides are recovered for recycle to an advanced reactor without extensive processing.

In this approach, recrystallization methods are used to achieve the desired separations in which the used nuclear fuel is dissolved in the molybdate melt containing a mixture of sodium molybdate $\left(\mathrm{Na}_{2} \mathrm{MoO}_{4}\right)$ and molybdenum trioxide $\left(\mathrm{MoO}_{3}\right)$ at temperatures between $1273-1473 \mathrm{~K}$, and $\mathrm{UO}_{2}$ (or transuranic oxides) recrystallize upon cooling, separating it from the fission products. [4-12] The process is based on the difference in solubility of the fission product metal oxides compared to the uranium (or transuranic) oxides in the molybdate melt.[4-12] The advantage of this process is that the fission products are more soluble in molybdate melt than the $\mathrm{UO}_{2}$. The fission product metals are oxidized in $\mathrm{MoO}_{3}$ and form molybdates, or other oxides, and the resulting products are soluble in $\mathrm{Na}_{2} \mathrm{MoO}_{4}$.[5] As the temperature of the system increases, the solubility of $\mathrm{UO}_{2}$ in $\mathrm{MoO}_{3}$ increases. At temperatures exceeding $1273 \mathrm{~K}$, any $\mathrm{UO}_{2}$ that dissolves in $\mathrm{MoO}_{3}$ forms $\mathrm{U}\left(\mathrm{MoO}_{4}\right)_{2}$.[7] In addition, most of the fission product oxides are also very 
soluble in $\mathrm{Na}_{2} \mathrm{MoO}_{4}$, while $\mathrm{UO}_{2}$ has very limited solubility, a property of the system that can be used for its separation from fission products. [4-11] Upon cooling to 973-1073 K, the fission products remain soluble in the melt, the mother liquor, whereas uranium precipitates as uranium dioxide or uranium molybdate, depending on the initial composition of the salt. [10-12] A wash of $\mathrm{Na}_{2} \mathrm{MoO}_{4}$ is then used to remove any remaining fission product oxides or molybdates from the uranium-bearing precipitate. [4-12]

Ustinov reported that recrystallization of $\mathrm{U}\left(\mathrm{MoO}_{4}\right)_{2}$ from a $\mathrm{UO}_{2}-\mathrm{MoO}_{3}$ melt containing fission products yielded a $98-99 \%$ purification from $\mathrm{Cs}, \mathrm{Ce}, \mathrm{Pr}, \mathrm{Zr}$, and $\mathrm{Nb}$; however only a $60 \%$ purification from $\mathrm{Ru}$ and $\mathrm{Rh}$ was achieved [1]. For the recrystallization of $\mathrm{UO}_{2}$ from a $\mathrm{UO}_{2^{-}}$ $\mathrm{MoO}_{3}-\mathrm{Na}_{2} \mathrm{MoO}_{4}$ melt, the purification from Cs, $\mathrm{La}, \mathrm{Zr}$ and $\mathrm{Nb}$ was $98.5-99.9 \%$ efficient. [4] There is no change in the oxidation state of uranium (or transuranics); therefore, no electrochemical methods or additional oxidants or reductants are required, and the actinide oxide product can be filtered from the fission products that remain in the melt.[10-12]

Small scale experiments using gram quantities of uranium have been performed to test the feasibility of using the molybdate melts to purify $\mathrm{UO}_{2}$ from fission products. In addition to looking at the feasibility of the molybdate melts, the method of contamination of the $\mathrm{UO}_{2}$ product by the fission products, and the optimum conditions for dissolution and precipitation of uranium oxide or molybdate and its separation from selected simulated fission product oxides were investigated. Our study explored $\mathrm{UO}_{2}$ recovery as a function of the composition of the molybdate melt, temperature, and precipitate washing with sodium molybdate. 


\section{Experimental}

\subsection{Materials}

Nickel based alloys were suggested to be suitable containers for studies conducted in these salt compositions $[4,5,9]$, but, severe corrosion was observed when Inconel (Sigma Aldrich) was used as a crucible and basket material in the presence of $\mathrm{MoO}_{3}$. A glassy carbon crucible was also experimented with in preliminary tests; however, the crucible corroded after prolonged use in molybdate melts. Platinum was selected for the crucible and basket construction based on its good corrosion resistance to molybdate melts. The platinum crucible, and mesh for the basket were both in-house materials. The crucible was 1.5 " in diameter by 1.5 " in height. In-house depleted uranium oxide pellets, $\mathrm{UO}_{2}$, were used as the source of uranium for the tests. Before processing, the pellets were crushed into smaller pieces to achieve faster dissolution.

Fission product oxide simulants and $\mathrm{Na}_{2} \mathrm{MoO}_{4}$ were purchased from Sigma Aldrich. The $\mathrm{MoO}_{3}$ was purchased from MP Biomedicals. The oxides and molybdates were homogenized by grinding with a mortar and pestle. The fission product oxide composition used in the study is given in Table 1. This composition is based on a calculated composition of fission products in the used fuel, with an initial enrichment of $3.2 \%$, after $33 \mathrm{MWd} / \mathrm{kg}$ burnup at a mean flux of $3.24 \times 10^{18} \mathrm{n} \mathrm{m}^{-2} \mathrm{~s}^{-1}$ in a typical pressurized water reactor after 10 years of cooling. [13] Select fission product oxides ( $\mathrm{Tb}, \mathrm{Dy}$, and $\mathrm{Er}$ ) are in a much higher concentration in the composition than what was calculated due to the difficulty in measuring such small quantities of the oxides in a glovebox. 


\subsection{Experimental Setup of the Melt}

Small-scale experiments containing six to seven grams of $\mathrm{UO}_{2}$ and approximately fifteen grams of $\mathrm{MoO}_{3}$ and $\mathrm{Na}_{2} \mathrm{MoO}_{4}$ in varying $\mathrm{MoO}_{3}: \mathrm{Na}_{2} \mathrm{MoO}_{4}$ ratios were performed in a vertical tube furnace inside an argon atmosphere glovebox with oxygen levels less than $10 \mathrm{ppm}$, and the moisture level between 3 and $50 \mathrm{ppm}$. Figure 1 displays a flowchart of the basic separations process. A diagram of the tube furnace and experimental setup is shown in Figure 2. The crucible was situated in the furnace and surrounded by Inconel heat shields. For uranium phase formation experiments, $\mathrm{UO}_{2}, \mathrm{Na}_{2} \mathrm{MoO}_{4}$, and $\mathrm{MoO}_{3}$ were loaded into the crucible without the basket, heated in the furnace at rate of about $573 \mathrm{~K} \mathrm{hr}^{-1}$ until the temperature reached $1473 \mathrm{~K}$, and held for about 8 hours to allow for the dissolution of $\mathrm{UO}_{2}$ in the melt. The temperature was monitored by a type $\mathrm{K}$ thermocouple. For fission product partitioning experiments, $\mathrm{UO}_{2}, \mathrm{Na}_{2} \mathrm{MoO}_{4}, \mathrm{MoO}_{3}$, and the fission product mixture were loaded into the basket and placed in the crucible. The mixture was heated at the same rate and to the same temperatures for the same amount of time, as the phase formation experiments. Because the melt was in a closed furnace, the possible release of gaseous fission products upon the dissolution of the simulated $\mathrm{UO}_{2}$ fuel into the melt could not be monitored. The melt was then cooled to a pre-determined temperature in the range of 973$1073 \mathrm{~K}$, at which point the uranium precipitated as an oxide or molybdate. The platinum basket was lifted out of the crucible to allow for the physical separation of the uranium product from the fission products, which remained in the salt phase. The temperature was held at 973-1073 K for about 10 hours to give ample separation time. When the system was cooled to room temperature, the precipitate was recovered. After the precipitate was recovered from the basket, the product was washed with approximately thirty grams of liquid $\mathrm{Na}_{2} \mathrm{MoO}_{4}$. 


\subsection{Composition of Uranium Product}

Experiments varying the composition of the initial melt of $\mathrm{MoO}_{3}, \mathrm{Na}_{2} \mathrm{MoO}_{4}$, and $\mathrm{UO}_{2}$ allowed for the determination of the composition of the main uranium-bearing precipitate upon cooling. Compositions of the melts studied are given in Table 2. To determine the composition of the uranium product from different compositions of the molybdate melts, samples of the uranium precipitate were analyzed using X-ray diffraction analysis (XRD). After cooling, samples of the uranium precipitate were transferred to a hood. The samples were ground and washed several times with de-ionized (DI) water to remove excess molybdate melt, and then air dried. A thin layer of powder was placed on a glass plate covered with double sided tape to allow the precipitate to adhere to the slide. The precipitate was then covered with a thin Mylar film. To identify the uranium-bearing phases obtained, the experimental XRD spectra were compared to the $\mathrm{PDF}^{1}$ database.[14]

\subsection{Dissolution of Uranium Product for ICP-MS Analysis}

After cooling, a portion of the uranium-bearing precipitate was removed from the basket and transferred for dissolution. Samples were first washed with $\mathrm{NaOH}$ to remove any residual molybdenum salts, and then washed with $0.1 \mathrm{M} \mathrm{HNO}_{3}$, which removes any remaining fission products that could be present on the surface of the precipitate. Due to the high solubility of sodium molybdate, $65 \mathrm{~g} / 100 \mathrm{~g} \mathrm{H}_{2} \mathrm{O}$, [15], deionized water with a resistivity $\geq 18 \mathrm{M} \Omega \mathrm{cm}$ was used to remove a significant portion of the molybdate salt present in the precipitate after the sodium molybdate wash. After several washes and decanting of the $\mathrm{UO}_{2}$ precipitate with water, the resulting precipitate was green/brown. The precipitate was initially suspended in the water wash, forming a green/brown solution. The precipitate eventually settled, leaving a yellow solution indicating the presence sodium molybdate in the wash, and the water wash was decanted away. This wash was performed several times. If sodium hydroxide was used instead of water, 
a clear solution formed. Sodium hydroxide was very effective for removal of molybdenum salts (>99.9\% of all Mo present in the precipitate). Both water and sodium hydroxide washes were also effective for the removal of any remaining cesium. When $\mathrm{Cs}_{2} \mathrm{O}$ was dissolved in $\mathrm{MoO}_{3}$ at temperatures exceeding $673 \mathrm{~K}, \mathrm{Cs}_{2} \mathrm{MoO}_{4}$ formed, which is very soluble in water. For precipitates containing uranium molybdates, a combination of $\mathrm{NaOH}$ and $\mathrm{H}_{2} \mathrm{O}_{2}$ was the most effective way for dissolution of the uranium molybdates $\left(\mathrm{UMo}_{2} \mathrm{O}_{8}, \mathrm{UMo}_{7} \mathrm{O}_{22}\right.$, and $\left.\mathrm{UMo}_{11} \mathrm{O}_{35}\right)$. On the other hand, precipitates obtained from mixtures with higher $\mathrm{Na}_{2} \mathrm{MoO}_{4}$ content were mostly $\mathrm{UO}_{2}$ and they dissolved in $\mathrm{HNO}_{3} / \mathrm{H}_{2} \mathrm{O}_{2}$ solutions. The product of mostly $\mathrm{UO}_{2}$ and possibly $\mathrm{Na}_{4} \mathrm{U}\left(\mathrm{MoO}_{4}\right)_{4}$, was then dissolved in $\mathrm{HNO}_{3}$ with the addition of $\mathrm{H}_{2} \mathrm{O}_{2}$ to accelerate dissolution of the $\mathrm{UO}_{2}$. Elemental analysis of uranium containing precipitates was performed using ICP-MS (PerkinElmer SCIEX ELAN DRC II) with a reported uncertainty of +/-10\%.

\section{Results}

\subsection{Uranium Speciation}

Figure 3 shows photographs of the precipitated products after they were recovered from the Pt mesh basket. Information regarding the composition of each melt, the color of the samples after rinsing with water, the major and minor uranium species identified, as well as the solubility of the product is provided in Table 2 .

\subsection{Fission Product Partitioning}

After dissolving the uranium product using the procedure discussed in Section 2.4, samples were analyzed using ICP-MS to determine the distribution ratio of the fission products remaining in the sample. To determine the effectiveness of the separation, the distribution ratio was calculated 
from ratio of the mass of fission product in the melt and the mass of fission product remaining in the uranium product:

$$
D=\frac{\text { Fission } \text { Product }_{\text {melt }}}{\text { Fission } \text { Product }_{U \text { Product }}}
$$

Distribution ratios for the fission products studied are provided in Figures 5-7.

\section{Discussion}

\subsection{Uranium Composition}

The composition of $\mathrm{MoO}_{3}$ and $\mathrm{Na}_{2} \mathrm{MoO}_{4}$ in the initial melts directly affected the uranium phase formed during precipitation. It was observed that melts consisting of a $\mathrm{MoO}_{3}$ mass fraction smaller than $\mathrm{UO}_{2}$ resulted in a $\mathrm{UO}_{2}$ precipitate as the major product. These results are consistent with the phase diagram produced by Ustinov et al. [5]. The phase diagram reveals that compositions consisting of much higher mass fractions of $\mathrm{MoO}_{3}$ result in $\mathrm{U}\left(\mathrm{MoO}_{4}\right)_{2}$. Results reported here confirm that $\mathrm{MoO}_{3}$-rich salt compositions $\left(\mathrm{MoO}_{3}>\mathrm{UO}_{2}\right)$ usually lead to the formation of the purple uranium molybdate precipitate $\left(\mathrm{U}\left(\mathrm{MoO}_{4}\right)_{2}\right)$.

Samples resulting in $\mathrm{UO}_{2}$ displayed good separation between $\mathrm{UO}_{2}$ and the excess molybdate salt. As seen in Figure 3, the product of Sample 1formed from the composition $20 \% \mathrm{MoO}_{3}$ $50 \% \mathrm{Na}_{2} \mathrm{MoO}_{4}-30 \% \mathrm{UO}_{2}$ showed two separate layers. The bottom dark layer is the $\mathrm{UO}_{2}$, which settled to the bottom of the crucible upon cooling, while the top yellow layer is the less dense excess $\mathrm{MoO}_{3}$ and $\mathrm{Na}_{2} \mathrm{MoO}_{4}$. After this sample was washed with water to remove the molybdate salt layer, it was analyzed by XRD. The XRD spectrum of this sample, Figure 4, confirmed the 
effective separation, as no molybdate salt remained in the sample. Based on XRD analysis, the product was identified as $\mathrm{UO}_{2}$.

To determine the effect of $\mathrm{Na}_{2} \mathrm{MoO}_{4}$ washes on the product's composition, two samples of the same composition $\left(60 \% \mathrm{MoO}_{3}-30 \% \mathrm{UO}_{2}-10 \% \mathrm{Na}_{2} \mathrm{MoO}_{4}\right)$ were analyzed, one with a $\mathrm{Na}_{2} \mathrm{MoO}_{4}$ wash (sample 6) and one without the wash (sample 5). Sample 5 resulted in a $\left(\mathrm{MoO}_{4}\right)_{2}$ product, which was to be expected with such a high concentration of $\mathrm{MoO}_{3}$. Sample 6 resulted in a $\mathrm{UO}_{2}$ product. According to Ustinov, the $\mathrm{Na}_{2} \mathrm{MoO}_{4}$ wash forms two incongruently melting compounds with the $\mathrm{U}\left(\mathrm{MoO}_{4}\right)_{2}$ left in the melt, and, upon cooling, these compounds decompose to a $\mathrm{UO}_{2}$ product in the temperature range between 973 and $1073 \mathrm{~K}$. [4] Our products from samples 5 and 6 confirmed Ustinov's findings. The ability of the $\mathrm{Na}_{2} \mathrm{MoO}_{4}$ wash to form the $\mathrm{UO}_{2}$ product from the $\mathrm{U}\left(\mathrm{MoO}_{4}\right)_{2}$ product demonstrated the necessity of the $\mathrm{Na}_{2} \mathrm{MoO}_{4}$ wash.

Ustinov et al. explained that the limited solubility of the $\mathrm{UO}_{2}$ in the $\mathrm{Na}_{2} \mathrm{MoO}_{4}$ is important because the $\mathrm{MoO}_{3}$ serves as the solvent, while the $\mathrm{Na}_{2} \mathrm{MoO}_{4}$ serves to precipitate the $\mathrm{UO}_{2}$. This explains the reason that melts consisting of $\mathrm{UO}_{2}-\mathrm{MoO}_{3}$ recrystallize $\mathrm{U}\left(\mathrm{MoO}_{4}\right)_{2}$, while melts consisting of $\mathrm{UO}_{2}-\mathrm{Na}_{2} \mathrm{MoO}_{4}-\mathrm{MoO}_{3}$ recrystallize $\mathrm{UO}_{2}$.[4]

\subsection{Fission Product Partitioning}

Figures 5-7 display the distribution ratios of the fission products in melts as a function of sample composition, temperature of the melt, and number of $\mathrm{Na}_{2} \mathrm{MoO}_{4}$ washes. In all of the melts, $\mathrm{Cs}$, $\mathrm{Sr}, \mathrm{Ru}$, and $\mathrm{Rh}$ displayed very large distribution ratios (D> 100), indicating good purification of the uranium product. Other fission products, including $\mathrm{Zr}, \mathrm{Pd}$ and the lanthanides (Ln) displayed smaller distribution ratios, (D>10), however, this purification is an adequate separation from the uranium product. In order to determine optimum conditions for the removal of the fission 
products with small distribution ratios (D>10) and to increase purification of the uranium product, the methods by which the fission products contaminate the uranium product was examined.

According to Tul'skii et al., the fission products have four methods by which they could contaminate the $\mathrm{UO}_{2}$ product[7]:

1. The fission product oxide could be dissolved in the mother liquor and entered the $\mathrm{UO}_{2}$ product via adsorption or trapping of the mother liquor onto the surface of the product.

2. The fission product oxide can interact with the uranium mixed molybdate $3 \mathrm{Na}_{2} \mathrm{MoO}_{4} \cdot 2 \mathrm{U}\left(\mathrm{MoO}_{4}\right)_{2}$, replacing the $\mathrm{Na}$ ion in the mixed molybdate.

3. The fission product oxide or molybdate could crystallize parallel to the $\mathrm{UO}_{2}$, but not be washed out during elutriation because the specific gravity of the fission product oxide is too close to the specific gravity of the $\mathrm{UO}_{2}$ product.

4. The fission product oxide could form a solid solution with the $\mathrm{UO}_{2}$, which would incorporate the fission product into the $\mathrm{UO}_{2}$ lattice during crystallization.

The first two methods of contamination could be reduced by washing the product with multiple $\mathrm{Na}_{2} \mathrm{MoO}_{4}$ washes. The $\mathrm{Na}_{2} \mathrm{MoO}_{4}$ wash would dissolve the fission product oxide on the surface of the product, removing the contaminant from the product. The $\mathrm{Na}_{2} \mathrm{MoO}_{4}$ wash would also react with the mixed molybdate contaminated with fission products, and decompose the uraniumbearing phase to the $\mathrm{UO}_{2}$ product. The third method of contamination is expected to be compensated for by physically lifting the Pt mesh basket with the $\mathrm{UO}_{2}$ product out of the mother liquor, thus separating the $\mathrm{UO}_{2}$ product from the mother liquor upon cooling. For example, in the case of $\mathrm{Ru}$, Tul'skii was able to conclude that the $\mathrm{Ru}$ crystallizes parallel with $\mathrm{UO}_{2}$ but can be 
separated if there are separate zones for crystallization.[7] These separate zones are achieved during the physical separation of the $\mathrm{UO}_{2}$ contained in the Pt basket upon cooling to temperatures low enough for the $\mathrm{UO}_{2}$ to precipitate, but higher than the crystallization temperatures of the fission product oxides. At these temperatures, while the $\mathrm{UO}_{2}$ is precipitating in the Pt basket, the liquid fission product oxides remain in the Pt crucible. The final method of contamination is considered the most common method of contamination for the fission product oxides, as most of the fission product oxides, especially the lanthanides, are known to form solid solutions with $\mathrm{UO}_{2}$. [16, 17]

\subsubsection{Effect of Melt Composition}

Figure 5 shows data from samples with varying $\mathrm{MoO}_{3}: \mathrm{Na}_{2} \mathrm{MoO}_{4}$ ratios at a constant concentration of $\mathrm{UO}_{2}$. The compositions containing 20, 30, and 50\% $\mathrm{MoO}_{3}$ were of interest because uranium phase composition experiments indicated that these $\mathrm{MoO}_{3}: \mathrm{Na}_{2} \mathrm{MoO}_{4}$ ratios produce the desired $\mathrm{UO}_{2}$ product. To investigate the effect of the melt composition on fission product partitioning, partitioning experiments heated to $1413 \mathrm{~K}$ were conducted because initial uranium phase composition experiments were performed at this temperature. When the same experiment was performed at $1313 \mathrm{~K}$, similar trends were seen for the partitioning of fission products from the $\mathrm{UO}_{2}$ product. The composition that displayed the best partitioning at $1413 \mathrm{~K}$ for the lanthanides and $\mathrm{Zr}$ is the $20 \% \mathrm{MoO}_{3}-50 \% \mathrm{Na}_{2} \mathrm{MoO}_{4}-30 \% \mathrm{UO}_{2}$ composition. From the uranium product composition experiments, this composition resulted in $\mathrm{UO}_{2}$ as the final product. The $\mathrm{UO}_{2}$ can be contaminated by the lanthanides and zirconium oxides during the crystallization process because of the formation of fission product oxide - uranium oxide solid solutions[16-18]. For example, as zirconium dissolves in the molybdate melt, the compound $\mathrm{ZrMo}_{2} \mathrm{O}_{8}$ forms, which incongruently melts and decomposes to $\mathrm{ZrO}_{2}$ [4]. Fission product contamination was 
lessened in the $20 \% \mathrm{MoO}_{3}-50 \% \mathrm{Na}_{2} \mathrm{MoO}_{4}-30 \% \mathrm{UO}_{2}$ melt because the high concentration of $\mathrm{Na}_{2} \mathrm{MoO}_{4}$ allowed for the increased solubility of the lanthanides and zirconium in the melt, forming molybdates, and the low concentration of $\mathrm{MoO}_{3}$ decreased the solubility of $\mathrm{UO}_{2}$ in the melt, decreasing the fission product oxide's opportunity to form solid solution with the $\mathrm{UO}_{2}$.

When the $\mathrm{Na}_{2} \mathrm{MoO}_{4}$ concentration was decreased below $50 \%$ and the $\mathrm{MoO}_{3}$ concentration was increased to the same level as $\mathrm{UO}_{2}\left(30 \% \mathrm{MoO}_{3}-40 \% \mathrm{Na}_{2} \mathrm{MoO}_{4}-30 \% \mathrm{UO}_{2}\right)$, the distribution ratios for the lanthanides and zirconium decreased. This result suggests that the solubility of the zirconium and lanthanide fission product oxides is directly proportional to the amount of the $\mathrm{Na}_{2} \mathrm{MoO}_{4}$ in the melt, which is consistent with the finding above. However, this trend was not seen in the composition $50 \% \mathrm{MoO}_{3}-20 \% \mathrm{Na}_{2} \mathrm{MoO}_{4}-30 \% \mathrm{UO}_{2}$, at $1413 \mathrm{~K}$, where the distribution ratios for zirconium and the lanthanides are greater than the $30 \% \mathrm{MoO}_{3}-40 \% \mathrm{Na}_{2} \mathrm{MoO}_{4}-30 \%$ $\mathrm{UO}_{2}$ composition. From the uranium product composition experiments, it was seen that the samples containing $30 \% \mathrm{MoO}_{3}-40 \% \mathrm{Na}_{2} \mathrm{MoO}_{4}-30 \% \mathrm{UO}_{2}$ formed a $\mathrm{UO}_{2}$ product, while the $50 \%$ $\mathrm{MoO}_{3}-20 \% \mathrm{Na}_{2} \mathrm{MoO}_{4}-30 \% \mathrm{UO}_{2}$ composition formed $\mathrm{UO}_{2}$ and $\mathrm{U}\left(\mathrm{MoO}_{4}\right)_{2}$ products. The increased solubility of the $\mathrm{UO}_{2}$ in the melt due to larger $\mathrm{MoO}_{3}: \mathrm{Na}_{2} \mathrm{MoO}_{4}$ ratios allowed for more $\mathrm{U}\left(\mathrm{MoO}_{4}\right)_{2}$ production, which possibly resulted in lower fission product oxides contamination.

The high distribution ratios of $\mathrm{Sr}$ and $\mathrm{Cs}$ appear almost independent (in log scale) of the weight factions of $\mathrm{MoO}_{3}$ and $\mathrm{Na}_{2} \mathrm{MoO}_{4}$. As $\mathrm{SrO}-\mathrm{UO}_{2}$ is known to form solid solutions [16, 17], the trace amount of Sr left in the product could be attributed to a solid solution of $\mathrm{SrO}_{2}$ formed with $\mathrm{UO}_{2}$, however, this trace amount of $\mathrm{Sr}$ is more likely present due to the interaction $\mathrm{SrMoO}_{4}$ with the mixed molybdate, $3 \mathrm{Na}_{2} \mathrm{MoO}_{4} \cdot 2 \mathrm{U}\left(\mathrm{MoO}_{4}\right)_{2}$. The removal of this type of contamination is discussed in a later section. 


\subsubsection{Temperature Effects}

Figure 6 displays the fission product partitioning that result from varying the temperature to which the melt was heated. The distribution ratio for the heavier lanthanides, and $\mathrm{Zr}$, appeared to be nearly constant at the two temperatures studied for the concentration of $30 \% \mathrm{MoO}_{3}$, while the lighter lanthanides, displayed better partitioning at the lower temperatures, especially for the $50 \% \mathrm{MoO}_{3}$ composition. As previously discussed, the lanthanides form solid solutions with $\mathrm{UO}_{2}$. [16-19] Increasing the temperature of the system increased the solubility of the $\mathrm{UO}_{2}$ in the $\mathrm{MoO}_{3}$. This increased solubility of the $\mathrm{UO}_{2}$ potentially allows for increased formation of the fission product oxide- $\mathrm{UO}_{2}$ solid solutions. This observation explains the greater purification of the lanthanides at the lower temperatures.

Another fission product that exhibited temperature dependence was $\mathrm{Ru}$, which had better partitioning at the higher temperatures. Unlike the rest of the fission product oxides, $\mathrm{RuO}_{2}$ is not soluble in $\mathrm{MoO}_{3}$.[4] $\mathrm{RuO}_{2}$ is also very volatile at temperatures exceeding $1173 \mathrm{~K}$, therefore, the higher temperature could lead to volatilization of Ru from the melt; however, our experiments were not designed to detect fission product vaporization.

\subsubsection{Effects of the $\mathrm{Na}_{2} \mathrm{MoO}_{4}$ Washes}

As seen in the uranium product composition experiments, the $\mathrm{Na}_{2} \mathrm{MoO}_{4}$ wash breaks down the $\mathrm{U}\left(\mathrm{MoO}_{4}\right)_{2}$ product to form a $\mathrm{UO}_{2}$ product. This approach is not the only application of the $\mathrm{Na}_{2} \mathrm{MoO}_{4}$ wash. One method for the fission product oxides to contaminate the uranium product is by dissolving in the mother liquor and adsorption or trapping of the mother liquor onto the surface of the $\mathrm{UO}_{2}$ product. Due to the slight solubility of the $\mathrm{UO}_{2}$ in $\mathrm{Na}_{2} \mathrm{MoO}_{4}$ and the large 
solubility of the fission product oxides in the $\mathrm{Na}_{2} \mathrm{MoO}_{4}$, washes using $\mathrm{Na}_{2} \mathrm{MoO}_{4}$ can remove this form of contamination by forming the fission product molybdates.

Fission product oxides can also interact with the mixed molybdate $3 \mathrm{Na}_{2} \mathrm{MoO}_{4} \cdot 2 \mathrm{U}\left(\mathrm{MoO}_{4}\right)_{2}$ by replacing the sodium ion[7]. Fission product molybdates and uranium molybdate are very soluble in $\mathrm{Na}_{2} \mathrm{MoO}_{4}$, therefore, multiple washes using $\mathrm{Na}_{2} \mathrm{MoO}_{4}$ decompose the mixed molybdate, removing the fission product contamination and purifying the $\mathrm{UO}_{2}$ product.

Figure 7 shows the distribution ratios of all the fission products after one or three $\mathrm{Na}_{2} \mathrm{MoO}_{4}$ washes performed for a composition of $30 \% \mathrm{MoO}_{3}-40 \% \mathrm{Na}_{2} \mathrm{MoO}_{4}-30 \% \mathrm{UO}_{2}$. The distribution ratio for $\mathrm{Cs}, \mathrm{Sr}, \mathrm{Rh}$ and $\mathrm{Pd}$ clearly indicated that surface or substitutional contamination occurred because the purification of the fission products increased by increasing the number of $\mathrm{Na}_{2} \mathrm{MoO}_{4}$ washes. When Tul'skii et al. performed experiments to remove trace amounts of Cs from $\mathrm{UO}_{2}$, they speculated that the Cs was incorporated into the mixed molybdate lattice of $3 \mathrm{Na}_{2} \mathrm{MoO}_{4} \cdot 2$ $\mathrm{U}\left(\mathrm{MoO}_{4}\right)_{2}$ by replacing the $\mathrm{Na}$ ion .[7] The high distribution ratio achieved for the Cs after multiple washes of $\mathrm{Na}_{2} \mathrm{MoO}_{4}$ suggest that nearly all of the Cs was removed from the $\mathrm{UO}_{2}$ product. The results of the $\mathrm{Na}_{2} \mathrm{MoO}_{4}$ washes indicate that the $\mathrm{Cs}$ is likely incorporated in the of $3 \mathrm{Na}_{2} \mathrm{MoO}_{4} \cdot 2 \mathrm{U}\left(\mathrm{MoO}_{4}\right)_{2}$ lattice (or surface contamination). Sr and $\mathrm{Rh}$ also exhibited reasonable purification from the final product with multiple washes of $\mathrm{Na}_{2} \mathrm{MoO}_{4} . \mathrm{SrO}$ is known to form $\mathrm{Sr}_{2} \mathrm{MoO}_{4}$ with $\mathrm{MoO}_{3}$, and $\mathrm{Rh}_{2} \mathrm{O}_{3}$ is very soluble in the $\mathrm{Na}_{2} \mathrm{MoO}_{4}$ and $\mathrm{MoO}_{3}$, which would result in their increased removal from the product with multiple washings. Little information is known of how Pd interacts with the $\mathrm{MoO}_{3}$ and $\mathrm{Na}_{2} \mathrm{MoO}_{4}$. Due to the increased purification that Pd displays with multiple washes of $\mathrm{Na}_{2} \mathrm{MoO}_{4}$, it is speculated that $\mathrm{Pd}$ contaminates $\mathrm{UO}_{2}$ either by 
dissolution in the mother liquor followed by adsorption or trapping of the mother liquor onto the surface of the UO, or by an interaction with the mixed molybdate.

None of the lanthanides exhibited a change in distribution ratio with additional $\mathrm{Na}_{2} \mathrm{MoO}_{4}$ washes, suggesting that the lanthanides did not contaminate the $\mathrm{UO}_{2}$ product by forming a mixed molybdate, and that the oxides does not dissolve in the mother liquor, and crystallize on the $\mathrm{UO}_{2}$ through trapping or adsorption. Tul'skii et al., claimed that Ce entered the $\mathrm{UO}_{2}$ lattice by forming a solid solution of $\mathrm{UO}_{2}-\mathrm{Ce}_{2}\left(\mathrm{MoO}_{4}\right)_{3}$ during crystallization. Tul'kii also claimed that the $\mathrm{Ce}_{2}\left(\mathrm{MoO}_{4}\right)_{3}$ dissolves in the mother liquor, and penetrates the $\mathrm{UO}_{2}$ by adsorption. [7] Figure 7 does not support this second claim, as the distribution ratio for Ce did not increase as the number of $\mathrm{Na}_{2} \mathrm{MoO}_{4}$ washes increase.

\section{Conclusion}

Molybdate melts demonstrated the ability to separate fission products from a uranium product for potential application of a modified open fuel cycle for used fuel treatment. Overall, the conditions we identified to achieve the purest uranium oxide product were:

1. A melt consisting of $20 \mathrm{wt} \% \mathrm{MoO}_{3^{-}} 50 \mathrm{wt} \% \mathrm{Na}_{2} \mathrm{MoO}_{4}-30 \mathrm{wt} \% \mathrm{UO}_{2}$

2. Heating the melt to $1313 \mathrm{~K}$ and performing the physical separation of the $\mathrm{UO}_{2}$ from the mother liquor.

3. Washing the uranium product once with $\mathrm{Na}_{2} \mathrm{MoO}_{4}$. 
It was determined that melt compositions containing more $\mathrm{MoO}_{3}$ than $\mathrm{UO}_{2}$ yield uranium molybdates as a major species, such as $\mathrm{UMo}_{2} \mathrm{O}_{8}$, while melts containing less $\mathrm{MoO}_{3}$ lead to the formation of $\mathrm{UO}_{2}$ precipitate as a major species.

The fission products investigated in the mock fuel displayed adequate partitioning from the uranium precipitate product. Certain fission products such as $\mathrm{Cs}, \mathrm{Sr}, \mathrm{Ru}$ and $\mathrm{Rh}$ displayed particularly good separations ( $\mathrm{D}=100-55000)$, while $\mathrm{Zr}$, and the lanthanides, had lower distribution ratios $(D=5-100)$. Distribution ratios greater than 10 are adequate for purification of the $\mathrm{UO}_{2}$. Zirconium and the lanthanides displayed the best partitioning in melts consisting of $20 \% \mathrm{MoO}_{3}-50 \% \mathrm{Na}_{2} \mathrm{MoO}_{4}-30 \% \mathrm{UO}_{2}$.

The fission product oxides exhibited better partitioning when the system was only heated to 1313 $\mathrm{K}$ as compared to $1413 \mathrm{~K}$. The $\mathrm{UO}_{2}$ and fission products were more soluble in the $\mathrm{MoO}_{3}$ at 1413 $\mathrm{K}$, which increased the opportunity to form solid solutions with the fission product oxides as the solution was cooled to precipitate the $\mathrm{UO}_{2}$.

A number of washes of $\mathrm{Na}_{2} \mathrm{MoO}_{4}$ allowed for greater removal of $\mathrm{Cs}, \mathrm{Sr}, \mathrm{Rh}$ and $\mathrm{Pd}$ contaminates from the $\mathrm{UO}_{2}$ by dissolving them into the wash solution. These contaminates were likely present in the $\mathrm{UO}_{2}$ from adsorption or trapping of the mother liquor onto the surface of the product, or interacting with the mixed molybdate $3 \mathrm{Na}_{2} \mathrm{MoO}_{4} \cdot 2 \mathrm{U}\left(\mathrm{MoO}_{4}\right)_{2}$ by replacing the $\mathrm{Na}$ ion. However, no obvious benefit in repeated washing steps was observed for $\mathrm{Zr}$ and lanthanides, and thus was not deemed necessary for purification of the $\mathrm{UO}_{2}$ product.

This study demonstrated the feasibility of using the molybdate process for the recovery of $\mathrm{UO}_{2}$ and provided insight into fission product partitioning during the process. However, a significant 
amount of work remains to be completed before the process can be used in the treatment of used nuclear fuel.

\section{References}

1. Laidler, J.J., et al., Development of pyroprocessing technology. Progress in Nuclear Energy, 1997. 31(1): p. 131-140.

2. Williamson, M.A. and J.L. Willit, Pyroprocessing Flowsheets for Recycling Used Nuclear Fuel. Nuclear Engineering and Technology, 2011: p. Medium: X; Size: 329-334.

3. McPheeters, C.C., R.D. Pierce, and T.P. Mulcahey, Application of the pyrochemical process to recycle of actinides from LWR spent fuel. Progress in Nuclear Energy, 1997. 31(1): p. 175-186.

4. Ustinov, O.A., The physical chemistry for regenerating spent uranium and plutonium oxide fuel by recrystallization from molybdate melts. Atomic Energy, 1997. 82(2): p. 99102.

5. Ustinov, O.A., L.P. Sukhanov, and S.A. Yakunin, Reprocessing of spent oxide nuclear fuel by recrystallization in molybdate melts. Atomic Energy, 2006. 101(4): p. 771-774.

6. Prokoshin A.D., U.O.A., Andrianov I.A., Chebotarev N.T., Matyushin E.A., , The $\mathrm{MoO}_{3^{-}}$ $\mathrm{PuO}_{2}$ System. Russian Journal of Inorganic Chemistry, 1976. 21(6): p. 854-856.

7. Tul'skii G.V., U.O.A., Behavior of Trace Impurities of Ruthenium, Cerium, and Cesium in the Crystallization of Uranium Dioxide from Molten $\mathrm{UO}_{2}-\mathrm{MoO}_{3}-\mathrm{Na}_{2} \mathrm{MoO}_{4}$. Radiochemistry, 1977. 19(3): p. 254-259.

8. Ustinov, O.A., et al., The system MoO3-UO3. Soviet Atomic Energy. 34(3): p. 203-205.

9. Ustinov, O.A., L.P. Sukhanov, and O.N. Pogorelko, Reduction recrystallization of uranium oxides in molybdate melts. Atomic Energy. 102(5): p. 361-363.

10. Hames A.L., T.P., Williamson M.A., Willit J.L. Investigation of Molybdate Melts fo Alternative Pyrochemical Reprocessing of Used Nuclear Fuel. in 2012 International Pyroprocessing Research Conference. 2012. Fontana, Wisconsin.

11. Tkac P., H.A.L., Cruse T.A., Willit J.L. Williamson M.A. . Alternative Pyrochemical Reprocessing of Used Nuclear Fuel Using Molybdate Melts. in 12th Information Exchange Metting on Actinide and Pission Product Partitioning and Transmutation 2012. Prague, Czech Republic.

12. Hames A.L., T.P., Paulenova A., Williamson M.A., Willit J.L. Investigation of $U$ Behavior in Molybdate Melts for Alternative Pyrochemical Reprocessing of Spent Nuclear Fuel. in American Chemical Society National Meeting. 2013. Indianapolis, Indiana.

13. Choppin, G.R., J.-O. Liljenzin, and J.A.N. Rydberg, CHAPTER 21 - The Nuclear Fuel Cycle, in Radiochemistry and Nuclear Chemistry (Third Edition). 2002, ButterworthHeinemann: Woburn. p. 583-641.

14. Liu, L.G., Eart Planet Sci. Lett, 1982. 1: p. 110.

15. Physical Constants of Inorganic Compounds, in CRC Handbook of Chemistry and Physics CRC Press. p. 87. 
16. Desal K.H., G.R.W., Parfitt D., Wiss T., Van Uffelen p., Atomic-scale SImulation of Soluble Fission Products in UO2, in EUR Report ISSN, E.C.-J.R.C.-I.f.T. Elements, Editor. 2009, E Institute fo Transuranium Elements.

17. Lang, S.M., et al., High-temperature reactions of uranium dioxide with various metal oxides. 1956, National Bureau of Standards, Washington, DC.

18. Cohen, I. and B.E. Schaner, A metallographic and X-ray study of the UO2-ZrO2 system. Journal of Nuclear Materials, 1963. 9(1): p. 18-52.

19. Evans, P., The system UO2-ZrO2. Journal of the American Ceramic Society, 1960. 43(9): p. 443-446.

20. Bell, W.E. and M. Tagami, HIGH-TEMPERATURE CHEMISTRY OF THE RUTHENIUM-OXYGEN SYSTEM1. The Journal of Physical Chemistry, 1963. 67(11): p. 2432-2436.

21. Garisto, F., Thermodynamic behaviour of ruthenium at high temperatures. 1988, Atomic Energy of Canada Ltd.

\section{Acknowledgements}

The submitted manuscript has been created by U Chicago Argonne, LLC, Operator of Argonne National Laboratory (“Argonne”). Argonne, a U.S. Department of Energy Office of Science laboratory, is operated under Contract No. DE-AC02-06CH11357. The U.S. Government retains for itself, and others acting on its behalf, a paid-up nonexclusive, irrevocable worldwide license in said article to reproduce, prepare derivative works, distribute copies to the public, and perform publicly and display publicly, by or on behalf of the Government. Argonne National Laboratory's work was supported by the U.S. Department of Energy, Office of Nuclear Energy, under contract DEAC02-06CH11357. 


\section{Figures}

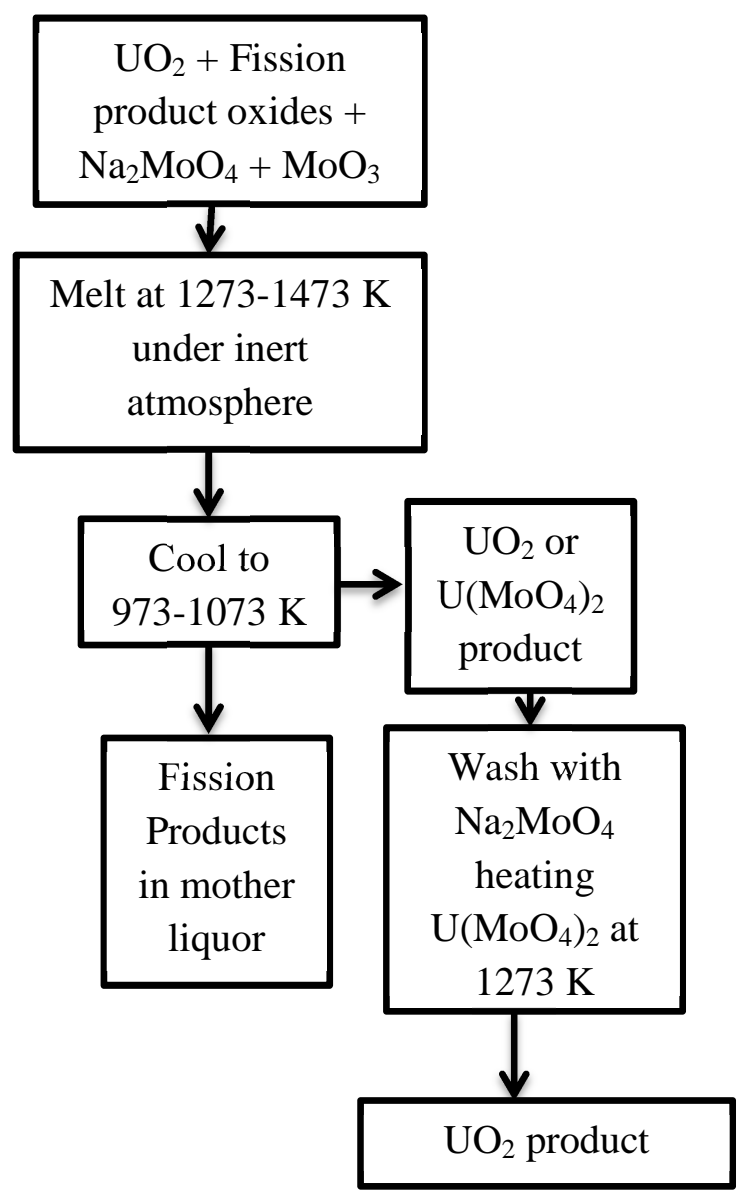

Figure 1. Flowchart diagramming $\mathrm{UO}_{2}$ partitioning in the molybdate melt. 
Fission Product Composition, mg of FP Metal/g-U

\begin{tabular}{|c|c|c|c|c|c|c|c|c|c|}
\hline \multicolumn{10}{|c|}{ Fission Product Composition, mg of FP Metal/g-U } \\
\hline Metal & $\begin{array}{c}\mathrm{Sr} \\
(\mathrm{SrO})\end{array}$ & $\begin{array}{c}\mathrm{Zr} \\
\left(\mathrm{ZrMoO}_{5}\right) \\
\end{array}$ & $\begin{array}{c}\mathrm{Ru} \\
(\mathrm{RuO}) \\
2\end{array}$ & $\begin{array}{c}\mathrm{Rh} \\
\left(\mathrm{Rh}_{2} \mathrm{O}_{3}\right)\end{array}$ & $\begin{array}{c}\mathrm{Pd} \\
(\mathrm{PdO})\end{array}$ & $\begin{array}{c}\mathrm{Cs} \\
\left(\mathrm{Cs}_{2} \mathrm{MoO}_{4}\right) \\
\end{array}$ & $\begin{array}{c}\mathrm{La} \\
\left(\begin{array}{c}\mathrm{LaO}_{2} \mathrm{O}_{3} \\
{ }^{2}\end{array}\right)\end{array}$ & $\begin{array}{c}\mathrm{Ce} \\
\left(\mathrm{CeO}_{2}\right) \\
\end{array}$ & $\begin{array}{c}\mathrm{Nd} \\
\left(\begin{array}{cc}\mathrm{Nd} \mathrm{O}_{3} \\
2\end{array}\right)\end{array}$ \\
\hline $\mathrm{mg} / \mathrm{g}-\mathrm{U}$ & 0.805 & 3.79 & 2.28 & 0.492 & 1.433 & 2.49 & 1.28 & 2.48 & 4.22 \\
\hline Metal & $\begin{array}{c}\mathrm{Sm} \\
\left(\mathrm{Sm}_{2} \mathrm{O}_{3}\right)\end{array}$ & $\begin{array}{c}\mathrm{Eu} \\
\left(\mathrm{Eu} \mathrm{O}_{2} \mathrm{O}_{3}\right)\end{array}$ & $\begin{array}{c}\mathrm{Gd} \\
\left(\mathrm{Gd} \mathrm{O}_{2}\right)\end{array}$ & $\begin{array}{c}\mathrm{Tb} \\
\left(\mathrm{Tb}_{2} \mathrm{O}_{3}\right)\end{array}$ & $\begin{array}{c}\text { Dy } \\
\left(\mathrm{Dy}_{2} \mathrm{O}_{3}\right)\end{array}$ & $\begin{array}{c}\mathrm{Er} \\
\left(\mathrm{Er}_{2} \mathrm{O}_{3}\right)\end{array}$ & $\begin{array}{c}\mathrm{Lu} \\
\left(\mathrm{Lu} \mathrm{O}_{2} \mathrm{O}_{3}\right)\end{array}$ & 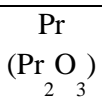 & $\begin{array}{c}\text { total FP } \\
\text { metals }\end{array}$ \\
\hline $\mathrm{mg} / \mathrm{g}-\mathrm{U}$ & 0.9 & 0.136 & 0.126 & $0.003^{*}$ & $\begin{array}{l}0.001 * \\
(0.138)\end{array}$ & $\begin{array}{l}0.001^{*} \\
(0.151)\end{array}$ & $\begin{array}{l}0.001 * \\
(0.127)\end{array}$ & 1.17 & $\begin{array}{c}21.6 \\
(\sim 2.2 \%)\end{array}$ \\
\hline
\end{tabular}

* larger quantities than expected for this mock fuel composition were actually used; the actual quantities are given in parenthesis below the calculated quantity.

Table 1. Fission product composition based on a calculated composition of 3.2\% enriched used fuel with $33 \mathrm{MWd} / \mathrm{kg}$ burnup at a mean flux of $3.24 \times 1018 \mathrm{n} \mathrm{m}^{-2} \mathrm{~s}^{-1}$ in a typical PWR after 10 years of cooling.[13] Fission product partitioning experiments contained about $2.2 \%$ of this composition in each melt. 


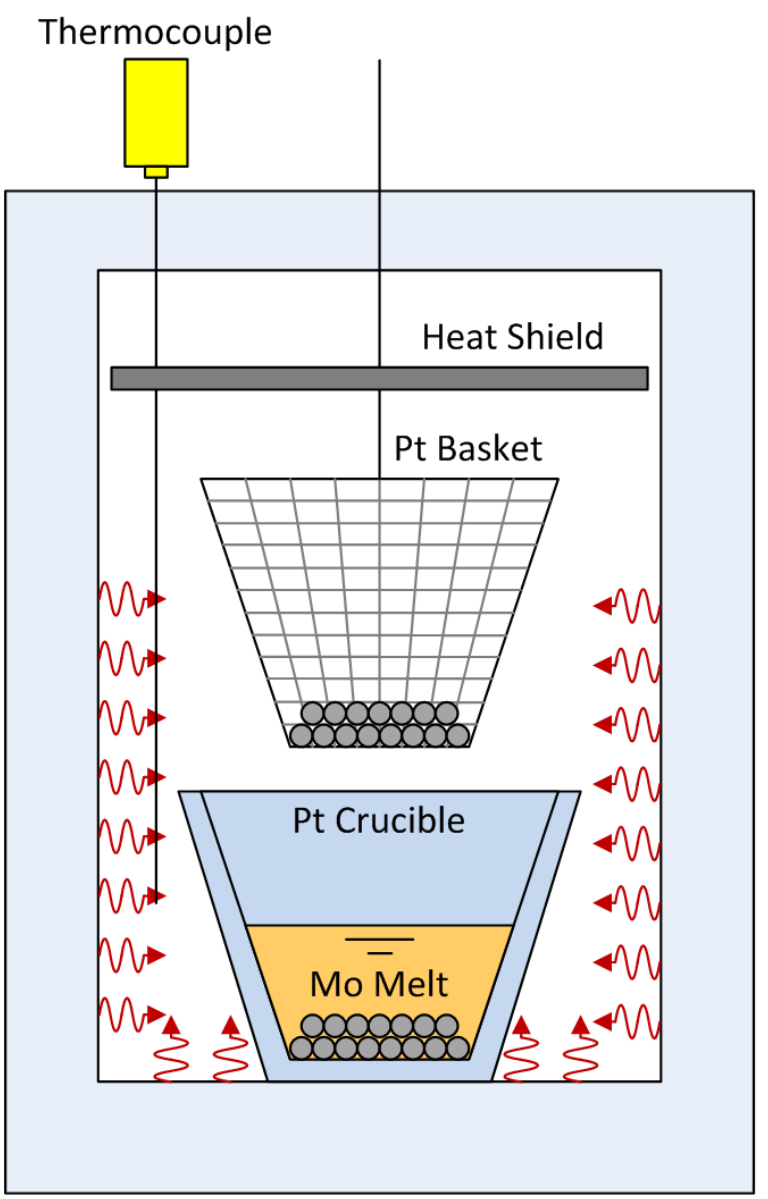

Figure 2. Experimental setup inside the tube furnace 


\begin{tabular}{|c|c|c|c|c|}
\hline $50 \% \mathrm{MoO}_{3} ; 50 \% \mathrm{UO}_{2}$ & $\begin{array}{c}50 \% \mathrm{MoO}_{3} ; 20 \% \\
\mathrm{Na}_{2} \mathrm{MoO}_{4} ; 30 \% \mathrm{UO}_{2}\end{array}$ & $\begin{array}{c}40 \% \mathrm{MoO}_{3} ; 30 \% \\
\mathrm{Na}_{2} \mathrm{MoO}_{4} ; 30 \% \mathrm{UO}_{2}\end{array}$ & $\begin{array}{c}30 \% \mathrm{MoO}_{3} ; 40 \% \\
\mathrm{Na}_{2} \mathrm{MoO}_{4} ; 30 \% \mathrm{UO}_{2}\end{array}$ & $\begin{array}{c}20 \% \mathrm{MoO}_{3} ; 50 \% \\
\mathrm{Na}_{2} \mathrm{MoO}_{4} ; 30 \% \mathrm{UO}_{2}\end{array}$ \\
\hline Sample 7 & Sample 4 & Sample 3 & Sample 2 & Sample 1 \\
\hline
\end{tabular}
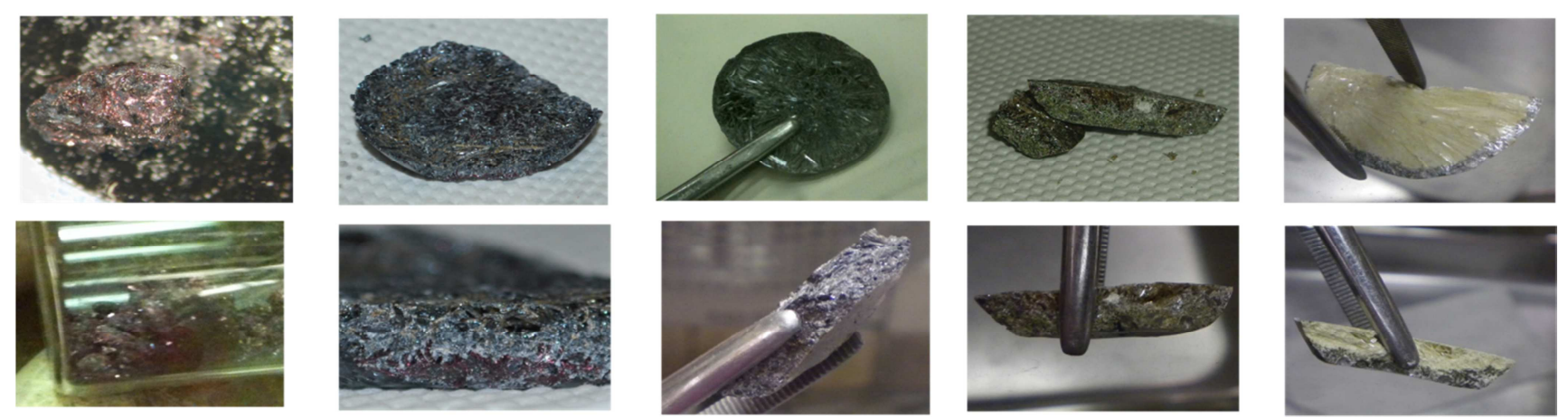

Figure 3. Photographs of uranium precipitates obtained from the melts of varying $\mathrm{MoO}_{3}$, $\mathrm{Na}_{2} \mathrm{MoO}_{4}$, and $\mathrm{UO}_{2}$ compositions. 


\begin{tabular}{|c|c|c|c|c|c|c|c|}
\hline \multirow{3}{*}{$\begin{array}{c}\text { Sample } \\
\# \\
1\end{array}$} & \multicolumn{3}{|c|}{ Initial Composition (weight \%) } & \multirow{3}{*}{$\begin{array}{l}\begin{array}{l}\text { Color after } \\
\mathbf{H}_{2} \mathbf{O} \text { wash }\end{array} \\
\text { gray-black }\end{array}$} & \multicolumn{2}{|c|}{ Species } & \multirow{3}{*}{$\begin{array}{c}\text { Soluble in } \\
\mathrm{Hot} \mathrm{HNO}_{3} / \mathrm{H}_{2} \mathrm{O}_{2}\end{array}$} \\
\hline & \multicolumn{2}{|c|}{$\mathrm{MoO}_{3} \quad \mathrm{Na}_{2} \mathrm{MoO}_{4}$} & $\mathbf{U O}_{2}$ & & \multicolumn{2}{|c|}{ Major Minor } & \\
\hline & $20 \%$ & $50 \%$ & $30 \%$ & & $\mathrm{UO}_{2}$ & & \\
\hline 2 & $30 \%$ & $40 \%$ & $30 \%$ & $\begin{array}{l}\text { gray, yellow- } \\
\text { green }\end{array}$ & $\mathrm{UO}_{2}$ & $\mathrm{Na}_{4} \mathrm{U}\left(\mathrm{MoO}_{4}\right)_{4}$ & $\begin{array}{c}\text { Hot } \mathrm{NaOH} / \mathrm{H}_{2} \mathrm{O}_{2} \text { partially } \\
\text { hot } \mathrm{HNO}_{3} / \mathrm{H}_{2} \mathrm{O}_{2}\end{array}$ \\
\hline 3 & $40 \%$ & $30 \%$ & $30 \%$ & brown-purple & $\mathrm{U}\left(\mathrm{MoO}_{4}\right)_{2}$ & $\mathrm{UMo}_{7} \mathrm{O}_{22}$ & $\begin{array}{c}\text { partially hot } \mathrm{HNO}_{3} \\
\text { partially hot } \mathrm{NaOH} / \mathrm{H}_{2} \mathrm{O}_{2}\end{array}$ \\
\hline 4 & $50 \%$ & $20 \%$ & $30 \%$ & $\begin{array}{l}\text { brown-purple- } \\
\text { gray }\end{array}$ & $\begin{array}{c}\mathrm{UO}_{2} \\
\mathrm{U}\left(\mathrm{MoO}_{4}\right)_{2}\end{array}$ & $\mathrm{Na}_{4} \mathrm{U}\left(\mathrm{MoO}_{4}\right)_{4}$ & $\begin{array}{l}\text { partially hot } \mathrm{HNO}_{3} / \mathrm{H}_{2} \mathrm{O}_{2} \\
\text { partially hot } \mathrm{NaOH} / \mathrm{H}_{2} \mathrm{O}_{2}\end{array}$ \\
\hline 5 & $60 \%$ & $10 \%$ & $30 \%$ & $\begin{array}{l}\text { dark blue- } \\
\text { purple }\end{array}$ & $\mathrm{U}\left(\mathrm{MoO}_{4}\right)_{2}$ & & $\begin{array}{c}\text { Hot } \mathrm{NaOH} / \mathrm{H}_{2} \mathrm{O}_{2} \text { partially } \\
\text { hot } \mathrm{HNO}_{3} / \mathrm{H}_{2} \mathrm{O}_{2}\end{array}$ \\
\hline 6 & $\begin{array}{l}60 \% \mathrm{Mo} \\
\text { washed } \mathrm{v}\end{array}$ & $\begin{array}{l}\mathrm{O}_{3}, 10 \% \mathrm{Na}_{2} \mathrm{I} \\
\text { vith } \mathrm{Na}_{2} \mathrm{MoO}_{4}\end{array}$ & $\begin{array}{l}30 \% \mathrm{UO}_{2} \\
1150{ }^{\circ} \mathrm{C}\end{array}$ & green-gray & $\mathrm{UO}_{2}$ & $\mathrm{Na}_{4} \mathrm{U}\left(\mathrm{MoO}_{4}\right)_{4}$ & $\begin{array}{c}\text { Hot } \mathrm{NaOH} / \mathrm{H}_{2} \mathrm{O}_{2} \text { partially } \\
\text { hot } \mathrm{HNO}_{3} / \mathrm{H}_{2} \mathrm{O}_{2}\end{array}$ \\
\hline 7 & $50 \%$ & \begin{tabular}{l|l} 
& -
\end{tabular} & $50 \%$ & purple & $\mathrm{U}\left(\mathrm{MoO}_{4}\right)_{2}$ & $\begin{array}{l}\mathrm{UMo}_{11} \mathrm{O}_{35} \\
\mathrm{UMo}_{7} \mathrm{O}_{22}\end{array}$ & $\mathrm{Hot} \mathrm{NaOH} / \mathrm{H}_{2} \mathrm{O}_{2}$ \\
\hline 8 & $70 \%$ & $10 \%$ & $20 \%$ & $\begin{array}{l}\text { dark blue, } \\
\text { purple }\end{array}$ & $\mathrm{U}\left(\mathrm{MoO}_{4}\right)_{2}$ & $\mathrm{UMo}_{7} \mathrm{O}_{22}$ & Hot $\mathrm{NaOH} / \mathrm{H}_{2} \mathrm{O}_{2}$ \\
\hline 9 & $30 \%$ & $10 \%$ & $60 \%$ & green-gray & $\mathrm{UO}_{2}$ & $\mathrm{Na}_{4} \mathrm{U}\left(\mathrm{MoO}_{4}\right)_{4}$ & Hot $\mathrm{HNO}_{3} / \mathrm{H}_{2} \mathrm{O}_{2}$ \\
\hline
\end{tabular}

Table 2. XRD results of uranium species precipitated from different compositions of $\mathrm{MoO}_{3}$, $\mathrm{Na}_{2} \mathrm{MoO}_{4}$, and $\mathrm{UO}_{2}$ 


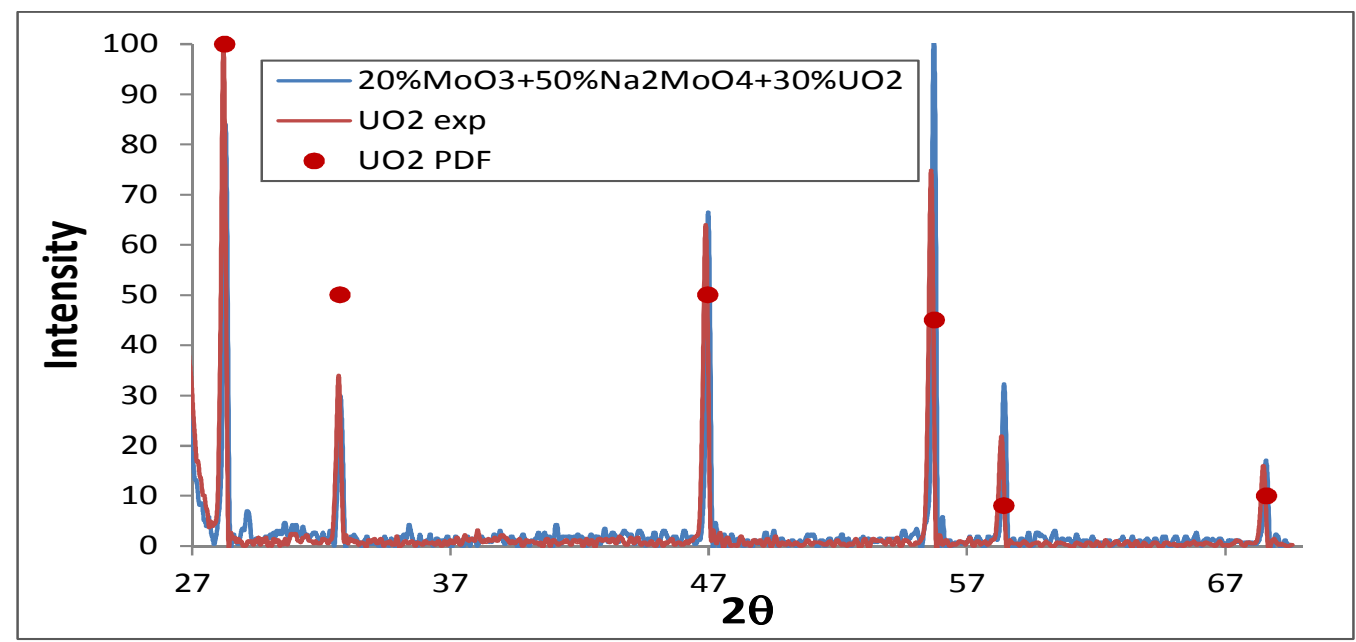

Figure 4. XRD pattern of uranium precipitate obtained from the salt mixture containing $20 \%$ $\mathrm{MoO}_{3}-50 \% \mathrm{Na}_{2} \mathrm{MoO}_{4}-30 \% \mathrm{UO}_{2}$ heated to $1313 \mathrm{~K}$ and cooled to room temperature. This spectrum is compared to a $\mathrm{UO}_{2}$ powder and a standard pattern for $\mathrm{UO}_{2}$. 


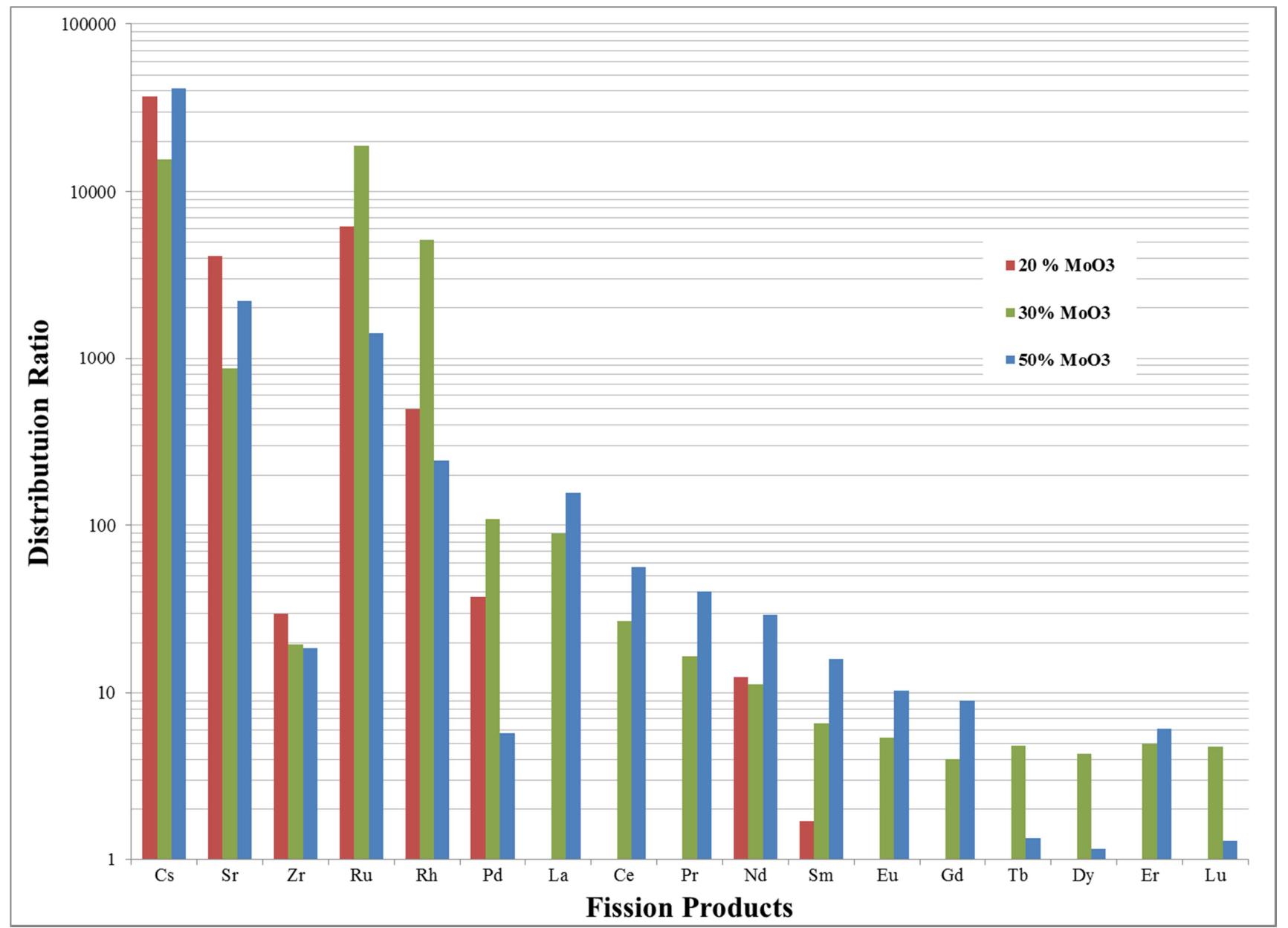

Figure 5. Distribution ratios for selected fission products at varying concentrations of $\mathrm{MoO}_{3}$ and $\mathrm{Na}_{2} \mathrm{MoO}_{4}$, and constant $30 \% \mathrm{UO}_{2}$. Samples were heated to $1413 \mathrm{~K}$ and cooled to $1223 \mathrm{~K}$ at a rate of $38 \mathrm{~K} \mathrm{~min}^{-1}$, and then were washed once with $\mathrm{Na}_{2} \mathrm{MoO}_{4}$. 


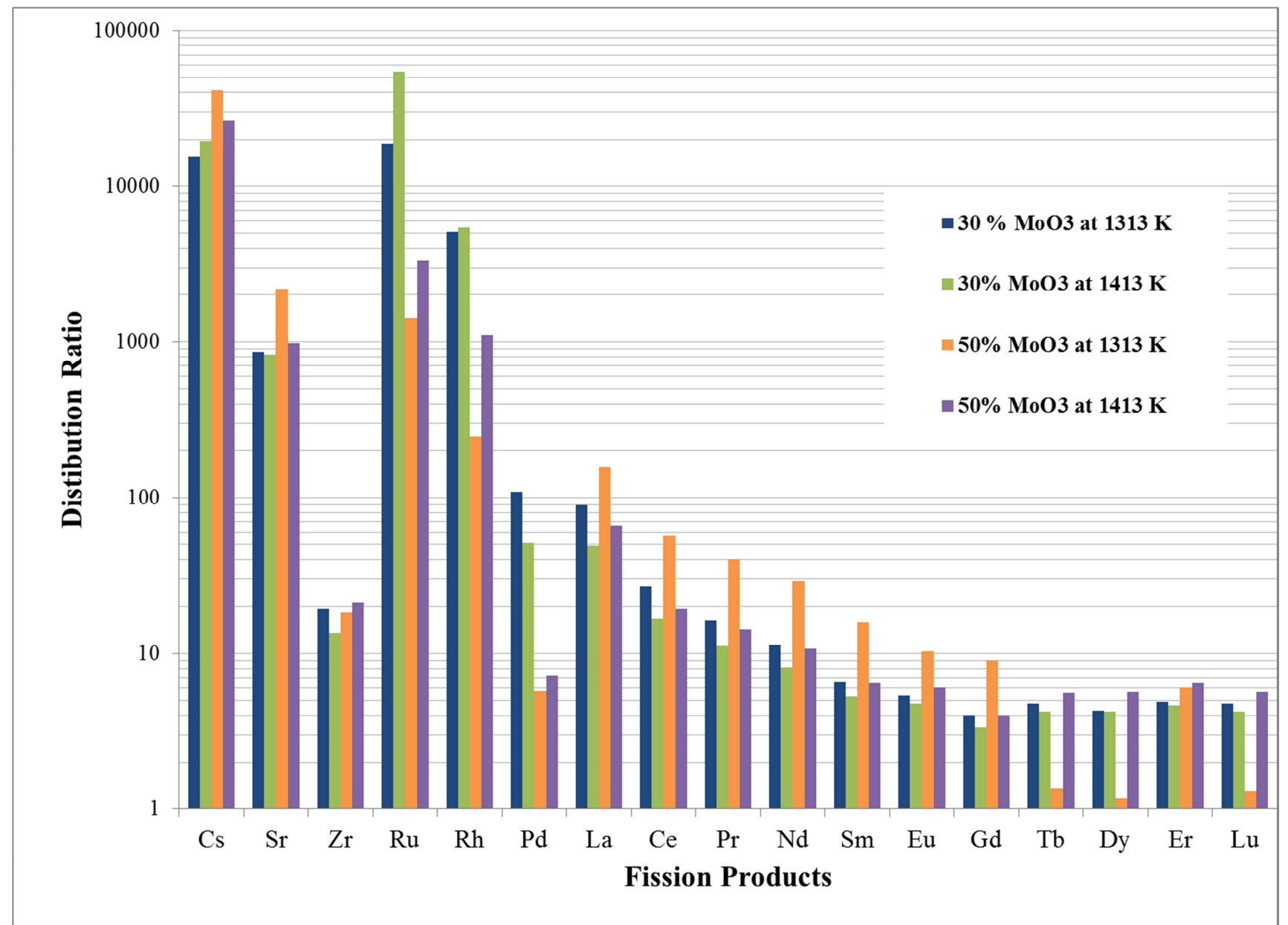

Figure 6. Distribution ratios of fission products from tests conducted at two dissolution temperatures followed by cooling at a rate of $38 \mathrm{k} \mathrm{min}^{-1}$. Samples contain $30 \% \mathrm{MoO}_{3}, 40 \%$ $\mathrm{Na}_{2} \mathrm{MoO}_{4}$, and $30 \% \mathrm{UO}_{2}$ and were washed once with $\mathrm{Na}_{2} \mathrm{MoO}_{4}$. 


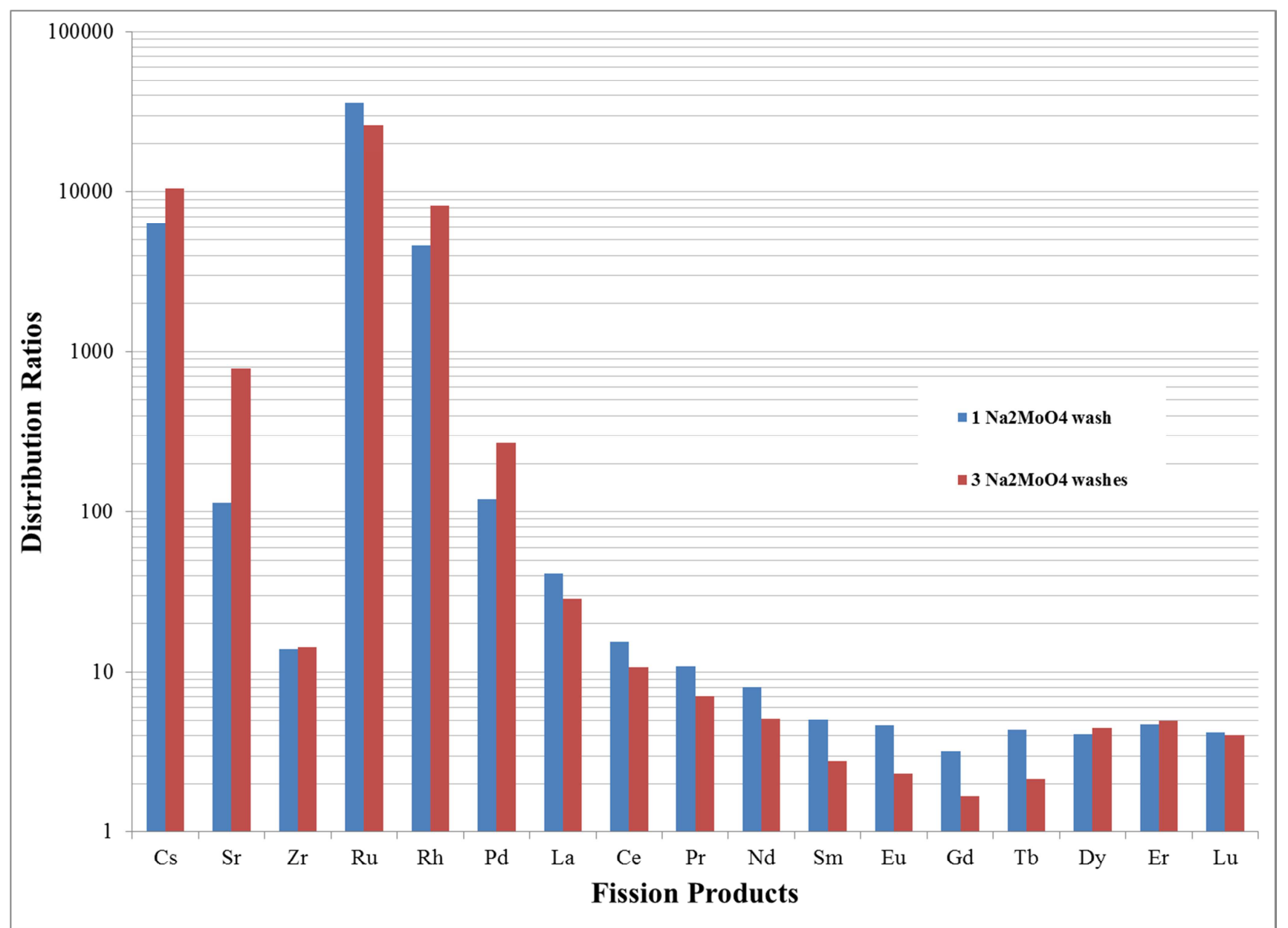

Figure 7. Distribution ratios of the fission products after uranium precipitate was treated with one or three $\mathrm{Na}_{2} \mathrm{MoO}_{4}$ washes. The precipitates were obtained from samples containing $30 \%$ $\mathrm{MoO}_{3}, 40 \% \mathrm{Na}_{2} \mathrm{MoO}_{4}$, and $30 \% \mathrm{UO}_{2}$ that were heated to $1413 \mathrm{~K}$ and cooled to $1223 \mathrm{~K}$ at a rate of $38 \mathrm{~K} \mathrm{~min}^{-1}$. 